\title{
Pengelolaan Kertagosa sebagai Daya Tarik Pariwisata di Kabupaten Klungkung
}

\author{
Ni Made Kariani ${ }^{*}$, Zuraidah ${ }^{2}$ \\ Program Studi Arkeologi, Fakultas Ilmu Budaya, Universitas Udayana. \\ ${ }^{1}$ [madekariani52@gmail.com], ${ }^{2}$ [ida_arkeounud@yahoo.com]
}

\begin{abstract}
Abstrak
Situs Kertagosa sebagai objek penelitian merupakan komplek bangunan kuno peninggalan kerajaan Klungkung, terdiri dari dua bangunan pokok yaitu Taman Gili dan Kertagosa. Kedua bangunan tersebut didirikan pada saat pemerintahan Raja I Dewa Agung Djambe pada akhir abad XVII yang merupakan bagian atas bangunan Puri Semarapura di Klungkung. Tinggalan arkeologi yang terdapat pada Situs Kertagosa meliputi dua bangunan utama, arca-arca kuno dan candi bentar. Penelitian ini bertujuan untuk memaksimalkan pegelolaan Situs Kertagosa. Penelitian ini menggunakan teori fungsional struktual dan teori manajemen sumberdaya budaya. Metoda pengumpulan data yang digunakan adalah metoda observasi, studi kepustakaan, dan wawancara. Teknik analisis data yang digunakan yaitu analisis kualitatif dan analisis SWOT. Potensi tangible meliputi dua bangunan utama; arca kuno, dan candi bentar. Potensi intangible meliputi nilai-nilai penting Situs Kertagosa. Faktor-faktor eksternal situs merupakan daya tarik yang terdapat di sekitar situs. Pemanfaatan segala potensi tersebut dapat menujang daya tarik Situs Kertagosa. Penentuan upaya yang tepat dengan menerapkan pedoman (perencanaan, pengorganisasian, pengarahan, pelaksanaan dan pengontrolan) dalam pengelolaan situs. Peningkatan mutu sumberdaya manusia, penambahan sarana dan prasarana, memakismalkan promosi, dan upaya penataan situs akan meningkatkan daya tarik Situs Kertagosa sebagai daya tarik pariwisata.
\end{abstract}

Kata Kunci: Situs Kertagosa, potensi, daya tarik pariwisata.

\begin{abstract}
Background of this research is Kertagosa Site as object of research is complex of ancient building relics of kingdom of Klungkung, consist of two main building that is Taman Gili and Kertagosa. Both buildings were established during the reign of King I Dewa Agung Djambe at the end of the XVII century which is part of the building of Puri Semarapura in Klungkung. Archaeological remains contained on the Kertagosa Site include two main buildings, ancient statues and gate. This study aims to maximize the management of the site and maximize the potential and supporting factors owned Kertagosa Site. This research uses structural functional theory and cultural resource management theory. The method used is the method of observation, literature study, and interview. Data analysis techniques used are qualitative analysis and SWOT analysis.These potentials Kertagosa Sites include; Tangible and intangible. The tangible potential includes two main buildings; Ancient statues, and temple bentar. The intangible potential includes important values of Kertagosa Sites. External factors of the site is an attraction that is located around the site. Utilization of all these potentials can boost the attractiveness of Kertagosa Sites. Determining the right effort by applying the 5P guidelines (planning, organizing, directing, implementing and controlling) is a great step in maximizing site management. Improving the quality of human resources, adding facilities and infrastructure, promoting promotion, and site structuring efforts will enhance the attractiveness of Kertagosa Sites as a tourist attraction.
\end{abstract}

Keywords: Kertagosa Site, potential, tourism attraction. 


\section{Latar Belakang}

Pariwisata merupakan salah satu andalan dalam mengangkat sektor perekonomian, penambahan lapangan pekerjaan bagi masyarakat, menambah pendapatan daerah dan negara. Bali mempunyai beragam potensi dalam sektor pariwisata, baik yang sedang berkembang maupun yang telah dikembangkan menjadi objek pariwisata. Sejak tahun 1974 pemerintah Provinsi Bali telah menetapkan bahwa jenis kepariwisataan yang dikembangkan di Bali adalah pariwisata budaya, dan saat ini telah ditetapkan dalam Perda Nomor 2 Tahun 2012 disebutkan bahwa kebudayaan Bali sebagai bagian dari kebudayaan Indonesia adalah landasan utama pembangunan kepariwisataan Bali, yang mampu menggerakan potensi kepariwisataan dalam dinamika kehidupan lokal, nasional, dan global (Ardika, 2015:62).

Sebagian besar daya tarik pariwisata di Bali merupakan tinggalan ataupun data arkeologi yang dikelola sebagai daya tarik wisata. Hal ini menujukkan bahwa tinggalan arkeologi tersebut telah mengalami komoditas atau proses komudifikasi untuk dikonsumsi oleh pengunjung. Komodifikasi adalah proses yang diasosiasikan dengan kapitalisme dimana objek, kualitas, dan tanda-tanda diubah menjadi komoditas, yaitu sesuatu yang utamanya untuk dijual di pasar (Barker dalam Ardika, 2008:2).

Salah satu sumberdaya arkeologi yang telah berkembang menjadi objek pariwisata adalah Situs Kertagosa. Komplek Kertagosa adalah bangunan kuno peninggalan kerajaan Klungkung, terdiri atas dua bangunan pokok yaitu bangunan Taman Gili dan bangunan Kertagosa. Kedua buah bangunan tersebut didirikan pada saat pemerintahan Raja I di Kerajaan Klungkung Dewa Agung Djambe pada akhir abad XVII, merupakan bagian dari bangunan Puri
Semarapura di Klungkung (Sutiari, 1980:9).

Bangunan Bale Kertagosa dan Bale Taman Gili merupakan dua bangunan utama yang terdapat pada Situs Kertagosa, terdapat juga beberapa sumberdaya arkeologi lainnya yang merupakan potensi pada Situs Kertagosa meliputi arca-arca yang di letakan di Kori Agung, Bale Kertagosa dan beberapa buah di Museum Semarajaya. Situs Kertagosa merupakan bagian integral dari Puri Agung Klungkung salah satu potensi sumberdaya arkeologi yang ada yaitu Kori Agung yang merupakan pintu masuk menuju Puri, memuat angka tahun (cakra, yuyu, yuyu, paksi) (1662) yang diperkirakan sebagai tahun berdirinya Kertagosa. Lukisan gaya kamasan yang menghiasi atap kedua bangunan merupakan daya tarik bagi pengunjung (Laksmi, 2013:211-212).

Situs Kertagosa merupakan daya tarik wisata andalan yang dimiliki oleh Kabupaten Klungkung. Menjaga kelestarian Situs merupakan hal yang penting. Memaksimalkan pola pengelolaan juga merupakan hal yang sangat perlu diperhatikan. Hal-hal yang perlu diperhatikan yaitu, memaksimalkan pemanfaatan potensi, daya dukung eksternal dan internal, fasilitas yang menunjang serta bentuk pelayanan dan kenyamanan yang diberikan kepada pengunjung. Memenuhi fasilitas umum yang menunjang pelayanan. Menjaga kelestarian Situs dapat dilakukan dengan langkah penetapan secara hukum dan perlindungan secara fisik dengan langkah zoning. Zonasi adalah penentuan batasbatas keruangan Situs Cagar Budaya dan Kawasan Cagar Budaya sesuai dengan kebutuhan (Tim Penyusun, 2010: 5-7).

Penentuan batas keruangan Situs dilakukan untuk mengakomodasikan kepentingan-kepentingan lain dalam pengelolaan sumberdaya arkeologi. Zonasi dapat dibagi kedalam tiga zona 
yaitu zona inti yaitu areal utama tinggalan arkeologi berada. Kemudian zona penyangga yang berada di luar zona inti, yang diperuntukkan bagi kegiatan penelitian arkeologi apabila diperlukan, dan zona pengembangan yaitu areal terluar yang diperuntukkan bagi pembangunan sarana dan prasarana yang diperlukan sesuai dengan rencana pemanfaatannya. Dari pemintakan ini dapat ditentukan batasan dari masingmasing zona sesuai dengan batasannya masing-masing (Suantika, 2012:194195).

Dalam mengelola sumberdaya arkeologi perlu memperhatika lima dasar pengelolaan sumberdaya budaya (CRM). Lima prinsip dasar pengelolan tersebut meliputi: plaining (perencanaan); organizing (pengoranisasian); directing (petunjuk atau pengarah); actuating (pelaksanaan); controling (pengontrolan evaluasi) (Kasnowirhadjo, 2001: 39). Kelima prinsif dasar pengelolaan tersebut harus diterapkan pada proses pengelolaan sumberdaya arkeologi agar tetap menjaga kelestarian situs dan tujuan sumberdaya arkeologi tersebut dikelola.

\section{Rumusan Masalah}

Berikut merupakan rumusan masalah berdasarkan pada latarbelakang penelitian

1. Apa saja potensi Situs Kertagosa sebagai daya tarik pariwisata di Kabupaten Klungkung

2. Bagaimana pengelolaan Situs Kertagosa sebagai daya tarik pariwisata di Kabupaten Klungkung

\section{Tujuan Penelitian}

Tujuan penelitian ini yaitu sebagai berikut.

1.untuk mengetahui potensi Kertagosa sebagai daya tarik pariwisata. 2.untuk mengetahui pengelolaan Kertagosa sebagai daya tarik pariwisata.

\section{Motode Penelitian}

Membahas permasalahan di atas digunakan beberapa teknik pengumpulan data yaitu teknik observasi, wawancara, dan studi pustaka. Setelah data yang dikumpulkan menggunakan teknik di atas terhimpun, selanjutnya dianalisis menggunakan analisis kualitatif dan analisis SWOT.

Analisis kualitatif yang menekankan pada pencatatan secara teliti segala fenomena yang dilihat, didengar, serta dibaca melalui pengamatan, wawancara, dan studi pustaka yang diungkapkan dalam bentuk deskripsi atau kata-kata. Analisis SWOT mengidentifikasi berbagai faktor secara sistematis untuk merumuskan strategi perusahaan. Analisis ini didasarkan pada logika yang dapat memaksimalkan kekuatan (Strengths), dan peluang (Opportunities), namun secara bersamaan dapat meminimalkan kelemahan (Weaknesses), dan ancaman (Threats).

Melalui metode yang digunakan tersebut penyusunan hasil penelitian yang diakukan dapat mencapai sasaran yang positif sesuai dengan yang diharapkan.

\section{Pembahasan}

\subsection{Potensi Situs Kertagosa}

Potensi dapat diartikan sebagai suatu yang dapat dikembangkan dan didayagunakan untuk menghasilkan sesuatu. Potensi yang dimiliki tersebut dapat berupa potensi budaya, yang dapat menarik minat wisatawan untuk berkunjung ke suatu daerah tertentu.

Suatu tempat dapat diartikan memiliki daya tarik dilihat dari kondisi lingkungan, dan daya dukung yang dimiliki pada suatu tempat. Daya dukung yang dimaksud, yaitu nilai sejarah, nilai seni, nilai estitika, sejarah ataupun agama 
yang dapat menarik keinginan untuk berkunjung.

Potensi sumberdaya budaya dapat digolongkan menjadi dua jenis yaitu potensi tangible dan potensi intangible. Sumberdaya intangible ialah yang bersifat konkret, akan tetapi tidak dapat dipegang seperti sastra, musik, tari, dan sebagainya.

Salah satu potensi yang sudah ataupun dapat dikembangkan sebagai daya tarik pariwisata adalah sumberdaya arkeologi. Sumberdaya arkeologi tersebut terkandung berbagai nilai, seperti nilai simbolik, informatif, estitika, dan ekonomi (Ardika, 2007:9-11). Salah satu sumberdaya arkeologi yang dikembangan sebagai daya tari wisata adalah Situs Kertagosa. Berikuta akan dibahas mengenai potensi tangible dan intangibel, faktor pendukung pada Situs Kertagosa.

\subsubsection{Potensi Tangible Situs Kertagosa}

Sumberdaya tangible merupakan sumberdaya berupa kebendaan, yang berwujud fisik serta dapat disentuh berupa benda asli buatan manusia. Artefak, bangunan, pondasi bangunan, monument dapat diambil sebagai contoh sumberdaya yang bersifat tangible. Adapun potensi tangible Situs Kertagosa meliputi:

\section{a. Bangunan Bale Kertagosa}

Bangunan Bale Kertagosa merupakan bagian dari Puri Klungkung. Asal kata Kertagosa terdiri dari dua kata yaitu krta yang berarti baik, luhur, rahayu dan gosita yang berarti diumumkan atau dipanggil. Berarti Kertagosa tempat untuk mengumumkan hal-hal yang baik (Sutiari, 1980:14).

Bangunan Bale Kertagosa merupakan salah satu bangunan kuno dengan style Bali yang terdapat di kompleks Kertagosa. Bale Kertagosa berbentuk segi empat yang terdiri atas bagian dasar dan atap. Bagian dasar terdiri atas dua tingkat terbuat dari batu padas dan batu bata serta dilengkapi dengan tangga. Bagian atap terbuat dari ijuk dan pada langit-langit bangunan (plafon) dihiasi dengan lukisan tradisional wayang dengan cerita Dyah Tantri, Bima Swarga, dan Palelintangan (Laksmi, 2013:211).

\section{b. Bangunan Bale Taman Gili}

Bale Taman Gili pada mulanya dibangun dengan ukuran yang lebih kecil dan pada mulanya bernama Bale Kambang. Bale yang berarti tempat dan kambang yang berarti terapung. Kemudian berubah nama menjadi Bale Gili yang berarti tempat yang berpulau (Sutiari, 1980:14)

Bale Taman Gili merupakan bagian dari kompeleks Situs Kertagosa. Struktur bangunan berada di tengah kolam, bentuk bangunan berbentuk bale segi empat tanpa tembok keliling. Bagian kaki dibuat berundak dengan dua lantai. Bagian dasar bangunan menggunakan batu padas dan batu bata bagian badan menggunakan kayu sebagai tiang dan atap menggunakan ijuk. Bale Taman Gili pada bagian atap juga dihiasi dengan lukisan gaya kamasan denga tema cerita Sutasoma, Pan Brayut, dan Palelintangan (Laksmi, 2013:2010).

\section{c. Arca}

Pada Situs kertagosa juga terdapat arca penjaga yang di tempatkan di Kori Agung (pintu masuk). Arca penjaga tersebut tidak seperti arca penjaga pada umumnya di Bali, arca tersebut berupa manusia yang berpakaian seperti tentara, memakai topi, dan membawa senjata. Hal ini menujukan perpaduan unsur moderen, bahwa penjaga pintu bukan hanya mengambil sosok yang seram, binatang atau berbadan besar, melainkan mengambil sosok manusai yang berperan dalam hal menjaga keamanan (tentara) (Laksmi, 2013:213). 


\section{d. Candi (Kori Agung)}

Kori Agung (candi kurung) merupakan pintu masuk yang terletak di sebelah selatan kompleks Situs Kertagosa menghadap ke arah utara Kori Agung ini dilengkapi dengan pintu kayu yang terus tertutup, di atas pintu terdapat angka tahun yang menunjukan tahun berdirinya Situs Kertagosa. Angka tahun tersebut berupa candrasangkala berupa cakra, уиуи, уиуи, paksi yang bernilai 1622 saka atau 1700 Masehi (Laksmi, 2013:211).

\subsubsection{Potensi Intangible}

Sumberdaya intangible merupakan sumberdaya non kebendaan, yang yang tidak berwujud fisik serta tidak dapat disentuh. Sumberdaya intangible tersebut dapat berup sejarah, nilai penting, makna, dan kesusastraan. Berikut merupakan potensi intangible Situs Kertagosa.

\section{Nilai Penting Situs Kertagosa}

Sumberdaya arkeologi yang dimiliki saat ini merupakan hasil karya pada masa lalu, keberadaannya saat ini memiliki nilai penting tersendiri yang mnelambangkan jati diri. Selain merupakan jati diri suatu bangsa, tinggalan arkeologi tersebut juga mempunyai nilai dan makna simbolik, informatif, estetik, dan ekonomi (Lipe 1984; Ardika: 2007). Berikut merupakan nilai penting pada Situs Kertagosa:

a. Nilai Kekuasaan: nilai kekuasaan pada Situs Kertagosa tercermin dari bangunan yang didirikan dan ada saat ini merupakan wujud dari kekuasaan raja terdahulu.

b. Nilai Estetika: nilai estetika tercermin dari bangunan, arca, lukisan pada banguan, dan ragam hias yang menunjukan nilai seni bagi yang melihatnya.

c. Nilai Ilmu pengetahuan: nilai ilmu pengetahuan tercermin dari lukisan, bangunan yang didirikan merupakan dedikasi ilmu pengetahuan dari yang merancang dan membuatnya.

d. Nilai Eonomi: nilai ekonomi pada Situs Kertagosa tercermin dari, kondisinya saat ini yang dikelola sebagai daya tarik wisata, sehingga akan bermanfaat bagi masyarakat luas.

e. Nilai arsitektur: nilai arsitektur tersermin dari bentuk bangunan arsitektur Bali, dengan bentuk dan hiasan yang sangat unik.

\subsubsection{Faktor-faktor Pendukung Situs Kertagosa.}

Pemanfataan dan pengembangan sumberdaya arkeologi sebagai daya tarik pariwisata, perlu dibarengi dengan memperhatikan situasi lingkungan sekitar objek sebagai penunjang kegiatan pariwisata. Lingkungan pada sekitar Situs Kertagosa merupakan faktor-faktor penunjang yang dapat menambah daya tarik pariwisata Situs Kertagosa.

Faktor pendukung pada Situs Kertagosa yang lokasinya tidak jauh dari Situs Kertagosa merupakan pendukung kuat untuk menambah day atarik, pendukung satu dengan yang lainnya sangat berkaitan erat dengan SitusKertagosa. Faktor-faktor pendukung tersebut meliputi Museum Semarajaya yang letaknya tidak jauh dari Situs Kertagosa, Puri Agung Klungkung, Monumen Puputan Klungkung, Pasar Seni Kungkung, Tukad Unda, dan Kampung Kamasan.

\subsection{Pengelolaan Situs Kertagosa}

Pengelolaan sumberdaya arkeologi mempunyai dasar filosofi yang mengaitkan kegunaan sumberdaya arkeologi untuk jati diri (cultural identity) yang dikaitkan dengan fungsi pendidikan, manfaat ekonomi, lewat kepariwisataan, dan fungsi akademis (Tanudirjo, 2004:3). Bentuk pengeolaan sumberdaya arkeologi pada umumnya 
akan menerapkan lima unsur dalam pengelolaan yaitu:

1. Planing: perencanaan

2. Organizing: pengorganisasian

3. Directing: petunjuk

4. Actuating: pelaksanaan

5. Controlling: pengontrolan (Kasnowihadjo, 2011:55).

Situs Kertagosa merupakan sumberdaya arkeologi yang dikembangkan sebagai objek wisata, yang dikelola oleh Pemerintah Daerah Kabupaten Klungkung (Dinas Pariwisata). Lima bentuk pengelolaan di atas dilaksanakan penuh oleh pihak Dinas Pariwisata. Selama proses pengelolaan terjadi beberapa hal yang menyimpang dalam prosesnya. Pemanfaatan ruang utama situs sebagai tempat praktek melukis, pedagang berjualan secara bebas, sarana umum yang belum lengkap, kerusakan beberap bagian pada bangunan, keseluruhan stakeholder yang belum terlibat, dan pengelolaan yang belum maksimal akan menghambat proses pengelolaan tersebut. Potensi serta faktor ekternal yang dimiliki Situs Kertagosa, menjadi peluang untuk dapat menyemibangkan kekurangan pada Situs Kertagosa.

Melalui analisis SWOT dan matrik SWOT akan menjadi langkah strategi pengelolaan Situs Kertagosa.

\section{Analisis SWOT Terhadap Situs Kertagosa}

Analisis SWOT dibagi menjadi dua faktor yaitu faktor eksternal dan faktor internal. Faktor eksternal terdiri dari peluang (opportunities) dan ancaman (threats). Faktor internal terdiri dari kekuatan (strengths) dan kelemahan (weakness). Analisis SWOT merupakan analisis yang dipergunakan dalam dunia pariwisata. Analisis SWOT merupakan identifikasi berbagai faktor secara sistematis untuk meningkatkan strategi perusahaan.
Analisis ini didasarkan pada logika yang dapat memaksimalkan kekuatan (strenghts) dan peluang (oppurtunities), namun secara bersamaan dapat meminimalkan kelemahan (weakness) dan ancaman (treath) (Rangkuti, 2003:18-19). Berikut merupak faktor ekternal dan internal Situs Kertagosa berdasarkan analisis SWOT.

a. Faktor Internal

Kekuatan (strenght) (S)

1. Potensi tangible dan intangible Situs Kertagosa.

2. Latar belakang sejarah Situs Kertagosa.

3. Lukisan gaya kamasan pada plafon bangunan Bale Kertagosa dan Bale Taman Gili.

4. Letak situs yang kompleks, dalam satu area terdapat museum Semarajaya.

\section{Kelemahan (Weakness) (W)}

1. Lahan parkir pengunjung.n

2.Tidak diterapkannya sistem zoning pada Situs Kertagosa.

3. Tidak tersedianya Fasilitas Informasi, Papan Larangan pada situs tersebut

4. Pedagang acung yang dapat berjualan dengan leluasa pada zona Inti Situs Kertagosa.

5. Retribusi tiket yang belum jelas pengelolaannya.

b. Faktor Eksternal

Peluang (Opportunities) (O)

1. Letak situs Kertagosa yang strategis, berada di pusat kota.

2. Akses menuju lokasi yang sangat mudah dan jalanan yang cukup baik.

3. Situs Kertagosa berdekatan dengan Objek Wisata lainnya. 
4. Praktek melukis gaya Kamasan yang terus dipraktekan setiap hari. Ancaman (Threats) (T)

1. Pengelolaan yang belum maksimal.

2. Kelestarian Situs.

3. Konflik kepentingan pengelolaan.

4. Setatus situs Kertagosa yang belum pasti secara administrasi

\section{Analisis Matrik SWOT Pengelolaan Situs Kertagosa sebagai Daya Tarik Pariwisata.}

Berdasarkan pada perpaduan antara faktor ekternal dan faktor internal yang didapat dari analisis SWOT menghasilakn empat set matrik SWOT berupa strategi yaitu sebagai berikut:

\section{Strategi SO}

-Penyedian SDM yang memadai.

-Pemasaran dan publikasi situs, melaksanakan kerjasama dengan berbagai pihak untuk mempromosikan Situs Kertagosa.

-Pengkemasan informasi kepariwisataan, sejarah, dan nilainilai Situs Kertagosa yang lebih menarik.

\section{Strategi ST}

-Memperhatikan kelestarian situs dan segala aset budayanya.

-Memaksimalkan lembaga-lembaga terkait dan benahi jalur kordinasi antar lembaga.

\section{Startegi WO}

-Penyediaan sarana dan prasaran.

-Memberikan pelatihan khusus bagi SDM yang dimiliki pihak pengelola.

-Meperhatikan dan memperhitungkan kembali manajemen sumberdaya arkeologi dengan jelas guna kelangsungan situs.

\section{Startegi WT}

-Penataan dan menjaga kelestarian situs untuk menjaga kesinambungan situs.

-Menentukan status kepemilikan dan pengelolaan situs, serta merancang susunan organisasi pasti.

\section{Saran Penataan Situs Kertagosa sebagai Daya Tarik Pariwisata \\ Penataan adalah kegiatan} mengatur dan menata dalam suatu susunan yang sistematis dengan memperhatikan kegunaan, bentuk dan sifat. Penataan kembali yaitu kegiatan mengatur dan menata kembali yang dulunya kurang diperhatikan dan optimal menjadi jauh lebih baik. Dari sisi zoning/letak fungsi ruang, hingga pemanfaatannya, dengan terpadunya sarana prasarana dan mendorong peran serta seluruh stakeholder dan pemerintah (Satrio, 2012:17-18).

Penataan Situs Kertagosa dalam menunjang kegiatan pariwisata menjadi salah satu upaya yang dapat dilakukan guna memberikan rasa nyaman wisatawan untuk berkunjung ke objek tersebut. Penataan tersebut tidak serta merta membangun bangunan, tetapi memaksimalkan bangunan, potensi dan fasilitas yang sudah tersedia pada situs tersebut. Penataan sumberdaya arkeologi tidak hanya sebatas sebagai sarana untuk meningkatkan kunjungan dan minat wisatawan berkunjung, diharapkan melalui penataan fasilitas dan memaksimalkan pemberdayaan sumberdaya arkeologi dapat menjaga kelestarian sumberdaya arkeologi agar nilai, makna serta kelesetarian situs dapat terjaga kesinambungannya, adapun upaya yang dapat dilakukan adalah sebagai berikut:

1. Upaya Pemeliharaan

2. Penambahan sarana dan prasarana

3. Memaksimalkan sumberdaya manusia 
4. Promosi dan pemasaran

5. Memaksimalkan pola pengeloaan (CRM).

\section{Penutup}

\subsection{Simpulan}

Adapun kesimpulan rumusan masalah penelitian adalah sebagai berikut:

1. Simpulan yang dapat ditarik dari rumusan masalah satu mengenai potensi Situs Kertagosa meliputi potensi tangible dan potensi intangible. Faktor-faktor ekternal Situs juga merupakan potensi Situs Kertagosa.

2. Simpulan yang dapat ditarik dari rumusan masalah kedua mengenai pengelolaan Situs Kertagosa, pengeolaan Situs yang berlum maksimal, belum dibentuknya susunan organisasi pengelola, sarana dan prasarana yang belum maksimal, dan peran stakeholder dalam pelaksanaan pengelolaan yang belum maksimal.

\subsection{Saran}

Saran untuk rumusan masalah satu, mengenai potensi Situs Kertagosa yaitu sebagai berikut:

1. Situs Kertagosa memiliki potensi yang meliputi potensi tangible, potensi intangible dan faktor-faktor pendukung sekitar situs. Segala potensi yang dimiliki Situs Kertagosa dapat dikembangkan dengan lebih maksimal lagi.

2. Selain mengembangkannya dengan lebih maksimal, perlu adanya sebuah langkah untuk menjaga segala bentuk potensi tersebut dengan langkah pemeliharaan yang baik, mengadakan konservasi pada bagian-bagian yang mengalami kerusakan, serta mencegah segala bentuk kerusakan dapat menjadi langkah untuk menjaga segala potensi tersebut.
Saran yang bisa diberikan untuk rumusan masalah kedua mengenai pengelolaan Situs Kertagosa.

1. Sumberdaya manusia (SDM). Pemberiaan pelatihan khusus baik kepada pemandu, pegawai yang bertugas menjaga kelestarian situs akan sangat efektif.

2. Merancang susunan organisasi, dan lembaga yang tergabung didalamnya, juga merupakan langkah yang efektif untuk meningkatkan kualitas pengelolaan.

3. Langkah untuk menjaga kelestarian situs dapat dilakukan tahapan pengkajian terkait zoning pada Situs Kertagosa. Penertiban pedang acung dan buatkan tepat khusus bagi atraksi melukis.

4. Melaksanakan kajian dan penerapan zonasi merupakan salah satu langkah untuk menjaga kelestarian situs, dalam zoning tersebut segala bentuk kepentingan akan diakomodasikan sesuai dengan fungsi dari masingmasing zona tersebut.

\section{DAFTAR PUSTAKA}

Ardika, I Wayan.2007. Pusaka Budaya Pariwisata. Denpasar : Pustaka Larasan.

2008. "Pariwisata dan

Komodifikasi Kebudayaan Bali" dalam Pusaka Budaua dan Nilai-Nilai Religius, Denpasar: Fakultas Sastra Universitas Udayana

2015. Warisan

Budaya Perspektif Masa Kini. Denpasar : Udayana University Press.

Kasnowihardjo, H. Gunadi. 2001. Manajemen Sumber Daya Arkeologi. Makasar: Lembaga Penerbitan Universitas Hasanuddin. Laksmi, AA Rai Sita. 2013. "Nuansa Kearifan Lokal Situs Kerta Gosa 
dalam Mengkontruksi Jatidiri Pada Era Global. Forum Arkeologi. Denpasar: Departemen Kebudayaan dan Pariwisata Balai Arkeologi.

Rangkuti, Freddy. 2011. Analisis SWOT Teknik Membedah Kasusu Bisnis. Jakarta: PT Gramedia Pustaka Utama.

Suantika, I Wayan. 2012. "Pengelolaan Sumberdaya Arkeologi Archeological Resources Management". Forum Arkeologi. Denpasar: Departemen Kebudayaan dan Pariwisata Balai Arkeologi.

Sutiari, I Gusti Ayu dan Kanta, I Made. 1980 Kertha Gosa. Direktorat Jendral Kebudayaan.

Tanudirjo, Aris Daud. 2004. "Manajemen Museum sebagai Daya Tarik Pariwisata Budaya". Yogjakarta: Jurusan Arkeologi Fakultas Ilmu Budaya Universitas Gadjah Nada.

Tim Penyusun. 2010 "Undang-undang Republik Indonesia No 11 Tahun 2010 Tentang Cagar Budaya". Kementrian Kebudayaan Dan Pariwisata Direktorat Jenderal Sejarah dan Purbakla.

Tim Penyusun. 2016. "Profil Kelurahan Semarapura Klod Klungkung". Direktorat Jenderal Pemerdayaan Masyarakat dan Desa Departemen Dalam Negeri.

Undang-undang Republik Indonesia Nomoe 10 Tahun 2009 Tentang Kepariwisataan. 